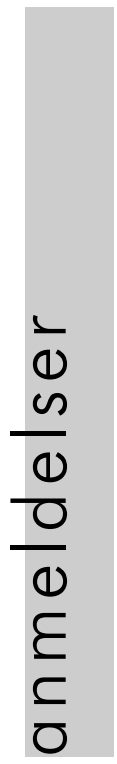

\section{Aktuel æstetisk teori}

Morten Kyndrup og Carsten Mdsen (red.), Asstetisk Teori? Asstetikstudier VII, Aarhus Universitetsforlag, Århus 2000, 312 sider, 198 kr.

Estetisk Teori? er syvende og sidste bind i skriftserien Æstetikstudier, der er blevet udgivet $\mathrm{i}$ forbindelse med forskningsprogrammet Moderne astetisk teori: Det astetiskes aktuelle funktionsforandring, som forløb ved Center for Kulturforskning, AU, 1993-98. Denne finale udgivelse med det beskedne, åbnende spørgsmålstegn i titlen rummer bidrag fra næsten samtlige forskere i Moderne astetisk teori-projektet. Hvert bidrag udgør et svar på formuleringen: "Med udgangspunkt i MÆT-projektets antagelse om aktuelle funktionsforandringer i det æstetiske felt ønskes en generel eller eksemplificeret fremstilling af disse ændringers konsekvenser for det æstetikteoretiske arbejde, sådan som det tager sig ud set fra din faglige synsvinkel."

Som man kunne forvente og ønske - afstedkommer en sådan formulering en række vidt forskellige fremstillinger, der vanskeligt lader sig sammenfatte, hvilket bogen da heller ikke forsøger, idet den uden hverken indledning eller afslutning lader bidragene stå alene i deres mangfoldighed og variation, bragt sammen $i \mathrm{kraft}$ af deres deltagelse i og dermed bestemmelse af det ubestemmelige xstetiske felt. Således spænder bidragene fra Jan Bäcklunds kryptiske, forførende sammenføringer af kunsten og skakspillet og fremlæsning af disse praksis' analoge historier og væsenslighed, hvori man på grund af sammenføringernes uventethed og ofte noget konstruerede kohærens til stadighed bliver opmærksom på Bäcklund selv (er han kunstner, æstetikteoretiker eller begge dele? Har han nedbrudt skellet mellem teoretisk og kunstnerisk praksis?), til Henrik Kaare Nielsens sobre, akademisk distancerede forsøg på efter Hegel og Adornos uddatering alligevel at etablere en samlende teoretisk indfaldsvinkel til hele det æstetiske felt i form af en sociologisk optik, hvorunder æstetik betragtes som en praksis- og erfaringskategori - det er betegnende for Kaare Nielsens på mange måder sympatiske nymarxistiske projekt, at han ikke nævner nogen kunstværker, men politiserende fokuserer på æstetiseringen af hverdagslivet.

MÆT-projektets dynamo, Morten Kyndrup lægger affirmativt, opbyggeligt ud med en klar og velargumenterende opstilling af syv $i$ hinanden indgribende områder, som kunstteorien må forholde sig til: kunst $\mathrm{og}$ kunstværk; kunst og essens; kunst og kunstforståelse; kunst, historie, historicitet; kunstværk og adgang; kunstværk og smagsdom; kunstværk og repræsentation. Det er Kyndrups pointe, at "en adækvat videnskabelig beskrivelse af 'det æstetiske' med særligt henblik på kunsten og dens aktuelle udfoldelse ikke kan underordnes ét og kun ét bestemt teoretisk anskuelsesperspektiv." Udpegende de syv felter indtager Kyndrup en art epistemologisk, metateoretisk position, der kan fungere som en perspektiverende forståelsesramme for de øvrige bidrag (der alle lader sig tænke i relation til et eller flere af disse 
felter), mens den anden redaktør, Carsten Madsen mere ontologisk i sin af Deleuze inspirerede minutiøse analyse af virtualiteten slutter af med at markere det immanensplan og den stadige tilblivelse, som udgør æstetikteoriernes og dermed de øvrige bidrags grundlag. Det er mellem disse redaktørernes positioner, æstetikteorierne udfoldes: ud over Bäcklund og Kaare Nielsen af Lene Tortzen Bager om autonomibegreb, Lars Kiel Bertelsen om fotografi, Erik Exe Christoffersen om performancekunst, Birgit Eriksson om dannelsesroman, Erik Gant om etnoæstetik, Carsten Juhl om globalæstetik, Ida Krøgholt om dramapædagogik, Niels Lehmann om pragmatik, Ansa Lønstrup om stemme, Karin Petersen om populærmusik og af Bodil Marie Thomsen om visuel repræsentation spændende fra Goethe over Grønlandsfilm til Orlan.

Trods en utilsløret heterogenitet viser der sig alligevel at være fællestræk ved de forskellige bidrag. Ud over den endnu uomgængelige Kant er eksempelvis Deleuze og den af Kyndrup i Danmark introducerede kunstteoretiker Thierry de Duve gennemgående såvel eksplicitte som implicitte referencer. Man kunne dog indimellem ønske sig, at de Duve og Deleuze bragtes $i$ anvendelse mere kritisk, forskudte og ikke så uimodsagte. De Duve er af central vigtighed, fordi han i sin genlæsning af Kant efter Duchamp, som i parentes bemærket er den kunstner, der ofte refereres til i udgivelsen, har gjort opmærksom på den moderne kunsts 'enunciative paradigme', hvor den kantianske smagsdom: "dette er skønt," er erstattet af den generelle æstetiske dom: "dette er kunst." Det betyder, at alt i princippet kan blive kunst, hvis det udråbes dertil, hvilket Bäcklund måske er et eksempel på. Sammen med dette enunciative paradigme hænger også kunstens installerethed og præsenterethed, hvilket er bidragenes mest gennemgående tema. Endelig er bidragyderne fælles om ikke at nævne ét ord om maleri - er maleriet, der vel trods alt mere end noget andet har virket konstituerende for vores nuværende kunstbegreb, da æstetikteoretisk dødt?

I det hele taget forekommer Æstetisk Teori? at være en vigtig, grænseafsøgende udgivelse, der ud over at rumme en række engagerede, tankevækkende og nybrydende læsninger og analyser er et udtryk for en levende, differentieret æstetik- og kunstvidenskabelig forskning, hvis eksistensberettigelse og nytteværdi synes åbenbar. Afsluttende må det bemærkes, at bogens egen æstetik vidner om, at 'den gode smag' ikke er helt fordrevet: omslag, opsætning, font og papirkvalitet minder $i$ al sin skønhed om det lækreste fra Gallimard. Anbefales.

Jacob Lund Pedersen 